\title{
The Taint of the Censor: J.M. Coetzee and the Making of In the Heart of the Country
}

Hermann Wittenberg, University of the Western Cape

With the publication of In the Heart of the Country (HOC) by the London publisher Secker \& Warburg in 1977, J.M. Coetzee had achieved international recognition for his second novel, transcending the narrow national literary culture of South Africa. Although HOC, with its overtly South African subject matter and setting further strengthened Coetzee's credentials as a significant new South African writer, a careful look at the publication history of this novel shows more of an ambivalence in the way Coetzee's authorship emerged in the force-field of tension between the local and the global. On the one hand, HOC's British publication was a further step in Coetzee's transnational authorship, a process that I have argued took place already with the writing and local South African publication of Dusklands (1974); ${ }^{1}$ on the other hand, Coetzee was also addressing himself for the first (and possibly last) time in a very particular and focused manner to a local readership. This complex doubled form of authorship was reflected in the dual publication history of HOC, both as an international version for the metropolitan Anglophone market (with a parallel US edition), as well as an edition published by Ravan Press in the following year, licensed for distribution only in South Africa. The South African edition distinguished itself not only by a different imprint and jacket design, but was decidedly local, with much of the novel's extensive dialogue in Afrikaans.

This paper will look at the fraught dual publication history of HOC and examine not only the problems associated with the short-lived experiment of a vernacular version of his novel, but also consider the implications for Coetzee's simultaneously global and locally situated form of authorship. As we will see, the debacle around the Ravan Press edition can be understood to have shaped Coetzee as a transnational author: a term whose meaning I take to describe a writer whose literature is alert to the local but whose meaning is independent of it. Or as Graham Huggan and Stephen Watson have put it, Coetzee is "essentially ... a first world novelist writing out of a South African context" (1996: 1). As a purely South African author, writing avant-garde fiction in both English and Afrikaans, Coetzee would not only have had a limited local readership, but also had to contend with the repressive political climate of the post-Soweto period in which the state stamped its authority on any form of dissent, and, conversely, the liberation movements' call for an intensified resistance. As an international author, Coetzee could allow himself a detached sense of postmodern discursive freedom; yet as a South African author pressures impinged on his writing either in the form of repressive state 
censorship or, equally problematically, in the call to arms for a more politically engaged artistic practice in the service of the anti-apartheid "struggle". ${ }^{2}$

In uncovering the story of these complex processes, and Coetzee's negotiation of these pressures, it is necessary to look more closely at material that has not been the subject of sustained attention by literary critics before, namely correspondence between the author and his publishers. 3 Rather than the conventional literary practice of textual analysis, a book historical approach will therefore be taken that considers the book as a socially constructed artifact, where meaning is shaped by "factors often beyond the control of authors themselves ... and how these processes are intimately connected with publishing pressures, the ruling discourses of reviewing, censorship, abridgment, educational institutionalisation, and the valorising economies of literary prize culture" (Van der Vlies 2004: 4). Book historical approaches are a fairly recent field in South African literary studies, and in Coetzee scholarship in particular4, allowing for new insights into the work of a significant author whose work has already attracted a large volume of critical scholarship.

With the positive critical reception of the debut novel Dusklands, published by the small, oppositional publishing house Ravan Press in 1974,5 Coetzee had not only established himself as major new voice on the South African literary scene, but had also become a commercially viable author whose books were selling briskly. Peter Randall, Ravan Press's prescient editor, had ordered a highly ambitious print run of 4500 copies, and this gamble was now paying off. It was not surprising then that Randall soon enquired about a follow-up novel, to which Coetzee regretfully replied as follows: "I wish I had something to offer; but I am, to put it crudely, stuck" (8 March 1975). By midyear however the overall plan and theme of HOC must have emerged, because Coetzee reported to Randall that he was "working on a book-length fiction" though he was concerned that the novel, "if published in South Africa, might conceivably be banned on one or both of the following grounds that (1) it impairs good race relations, (2) it is obscene etc" (27 June 1975). HOC's narrative of a dysfunctional rural Afrikaans farming family that became embroiled in sexual relations across the colour line, culminating in the repeated forced sexual encounters between the narrator/protagonist Magda and the farm foreman, would have sat uncomfortably with the censors of the apartheid state in which such interracial contact and humiliation of a white woman was punishable under the Immorality Act. As Coetzee himself later put it in the book's blurb, the novel's "sensational plot" revolved around a "lurch across the colour bar". Already at the stage of the novel's conceptualization, we must assume that Coetzee was well aware that his book was going to challenge the censorship laws on two fronts: firstly, that the novel was politically transgressive of the apartheid interdiction against depictions of inter-racial sex; and secondly, that the explicit descriptions of sexual contact might be deemed pornographic. As we will see later, the actual censor reports considered these questions,

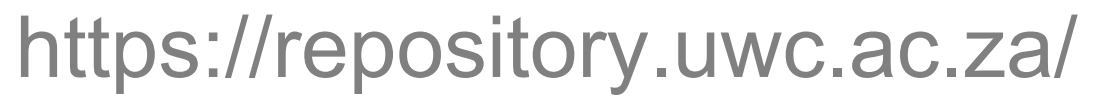


but ultimately found the book "not undesirable". It is clear though that Coetzee considered the threat of censorship while writing the novel, and that, in his mind, it stood a real chance of not being published in South Africa. This emerges in the following questions addressed to Randall:

Assuming that Ravan were interested in publishing the book, and assuming that I had no objections, would you be prepared to submit the MS to the Publications Control Board for scrutiny? And if they asked for cuts, what would you do? If you were not prepared, on principle, to submit any MS to the PCB, would you be prepared to publish a book which, although in your opinion of literary merit, stood a good chance of having official action taken against it? (8 March 1975)

Coetzee's concerns with South African publication are here is framed in a number of hypothetical questions and concerns. Apart from his anxiety about the possibility of censorship and banning (even before the book was written), he was also conscious of the financial risk that Ravan would have to take. Later he would ask Randall explicitly if "Ravan Press [is] in a position to survive the financial effects of a banning?" (26 March 1976). Although the publisher had earlier that year suffered financial consequences after the banning of Wopko Jensma's book, Peter Randall informed Coetzee that Ravan had "taken a policy decision that we shall not under any circumstances submit a ms. to the PCB" (21 July 1975). A few months later, Coetzee let Randall know that the writing was proceeding well:

The book I am working on is going well, and I have the prospect of a long slack period at UCT while students write examinations, followed by a 3 -month vacation. I watch myself carefully to see whether I notice this notorious sense of the-censor-at-myelbow that people write about, but I haven't found it yet. (30 September 1975)

Coetzee's candid and self-reflexive comment about the impact of the country's censorship laws clearly shows that the matter was on his mind throughout the novel's writing process. Even if the writing process itself remained uncontaminated by the threat of censorship, as Coetzee suggests it was, he was clearly aware of the fact that he was writing in an environment in which the censor had power over the publication of his book. The "contagious power" of the censor that "touched and contaminated" the writing process was later more fully explored in Giving Offense, Coetzee's collection of essays on censorship (1996: 35). Coetzee here explored the psychologically intrusive effects on the writer, akin to a form of forceful yet intimate violation:

Working under censorship is like being intimate with someone who does not love you, with whom you want no intimacy, but who forces himself upon you. The censor is an intrusive reader, a reader who forces his way into the intimacy of the writing

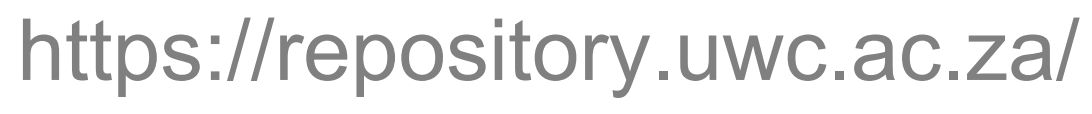


transaction, forces out the figure of the beloved or courted reader, reads your words in a disapproving and censorious fashion. (1996: 38)

Although cast in general terms, Coetzee was no doubt reflecting here on the writing of HOC, rather than his subsequent novels. HOC was written during the years of the opaque and arbitrary censorship bureaucracy under Judge Lammie Snyman who chaired the Publication Control Board into the late 1970s. After the showdown between Afrikaans writers and intellectuals and the state in 1978 around the controversial banning of Ettienne Leroux's novel Magersfontein, O Magersfontein!, a more moderate and reformist Publications Control Board under the chairmanship of Prof. J van Rooyen took control that sought to bring a measure of rational certainty and scientific rigour to the process. ${ }^{6}$ But nevertheless, we can assume that Coetzee's view of censorship was primarily shaped by the experience of writing HOC under the older, geroncratic Snyman regime, caricatured yet recognizable in Giving Offense as "the dark-suited, bald-headed censor, with his pursed lips and his red pen and his irritability"(1996:38). Ironically, as we shall see, Coetzee's actual censors were not unimaginative, grey government bureaucrats, but intellectuals, writers and academics like himself, among them even colleagues at the University of Cape Town where he was teaching.

Early in 1976, Coetzee announced to Randall that "the book" he is "presently working on" should be finished by the beginning of June, and also asked if there was any truth in the rumour that "Ravan is about to fold" (26 March 1976). If we look the themes that emerge in his interactions with Randall during the course of 1975 and the first half of 1976, Coetzee was clearly concerned about the viability of publishing HOC in South Africa given the harsh prevailing censorship regime. He was equally concerned about the prospect of entrusting his novel to a publisher whose financial future was uncertain. Despite Randall's assurance about Ravan's continued viability, the publisher was always in a precarious position due to its non-commercial publishing programme, and the risks it took in printing books that courted banning. Furthermore, as we have seen, Coetzee was not only troubled by the impact that possible censorship would have on the publication and sales of his novel, but also its insinuation into the writing process itself. The obvious solution to all the above problems would be an overseas publication of HOC with a major international publisher. Given the problems associated with a South African publication, it is therefore not surprising to notice Coetzee's lack of firm commitment to Ravan, despite keeping Randall informed about the novel's progress.

The only obstacle to taking the route of international publication lay in the form of the manuscript itself: the extensive use of Afrikaans dialogue. Ravan, as Coetzee had ascertained in March 1976, had no objection to publishing a substantially bilingual text, but this would evidently not work on the British or US market. By the end of May, Coetzee, working rapidly, already had an English-only version of HOC completed, of

$$
\text { https://repository.uwc.ac.za/ }
$$


which two copies were mailed to Ravan for consideration for the Mofolo-Plomer Prize. 7 Coetzee also asked Randall if Ravan would be prepared to publish this version of the novel (21 May 1976). Randall took more than a month in replying that he wanted to publish HOC, irrespective of the outcome of the Mofolo-Plomer Prize adjudication (29 June 1976), but by then matters had taken an irrevocably different turn, both in respect of the book as well as the country as a whole: on 16 June 1976, Soweto erupted in protest action by black school children that soon engulfed the entire country in violence, leading to a major crisis for the apartheid state. To Coetzee, no doubt appalled by the deteriorating political situation and the ensuing brutal crackdown of the state's security forces, it must have been clear that the climate for publishing HOC in South Africa had dramatically deteriorated. Although it seems likely that he had submitted the manuscript to Secker \& Warburg some weeks before the sudden eruption on the streets of Soweto (perhaps soon after, or even before approaching Ravan at the end of May), the decision to opt for international publication was no doubt re-enforced by the disturbing political situation in South Africa.

On 9 July 1976, Coetzee wrote to Randall, informing him that Secker \& Warburg had agreed to publish HOC, and that they also wanted rights to the South African market, effectively closing his relationship with Ravan. He explained his decision to abandon Ravan as follows: "At some moment or other I have to break out of the local market, and it appears that if one writes minority-taste novels one has to offer up the local market as the price for overseas publication." There was however an attempt to offer some token of consolation: Secker \& Warburg were prepared to tolerate a separate South African edition "on condition that it appears no earlier than nine months after original publication at a price that does not undercut Secker's price." But even Coetzee conceded that this was "obviously ... not a viable proposition" (9 July 1976).

It is not difficult to imagine Randall's shock in receiving this unexpected news, especially after having already accepted HOC for publication and being kept informed of the novel's progress for more than a year. He however generously congratulated Coetzee on his success, and agreed that a separate Ravan edition was not viable under the circumstances: he would only publish a South African edition if Secker's "edition is not marketed in South Africa". He ended the letter saying that he "would, of course, be glad if the book could mention somewhere that your first novel was published by Ravan" (21 July 1976). When HOC eventually appeared under the Secker \& Warburg imprint it must have pained Randall to notice that Ravan warranted no mention. With this exchange of correspondence, Coetzee's relationship with Ravan seemed to have come to an abrupt end, and there is no record of any communication for a period of almost a year. In later interview with Hugh Roberton, Coetzee explained his decision to opt for international publication in overtly financial terms:

\section{https://repository.uwc.ac.za/}


While the British book manufacturer (let us call him that for the moment) may have the organization to market his products in South Africa, it is unlikely that the South African book manufacturer will have the organization to market his products in Britain. Economics, therefore dictate that ... it is more profitable for everyone concerned that the publisher be British. (1983:12)

Randall later reflected on the episode by saying that "Ravan was a very small, essentially non-commercial publisher, and we would not be able to match Secker in terms of sales etc. JMC was obviously an exceptional talent and we did not want to stand in his way of reaching a world readership" ("Notes", 2007). But Coetzee also sympathized with local publishers such as Ravan who could not effectively compete against major first-world presses. In a 1978 interview with Stephen Watson, Coetzee identified the unequal playing field which made local publishing unviable:

Publishing-wise, you know, we're in a pure colonial situation in that, so to speak, our literary products are flown to the metropolitan centre and re-exported to us at a vastly increased price. And this goes for me, it goes for almost any writer in this country today. (1978: 24)

Coetzee's reference to a "pure colonial situation" to describe the dominance of metropolitan presses appears particularly apt when looking at the way in which Secker conducted itself with regard to Ravan, riding rough-shod over local sensibilities and constraints. This interaction will be looked at more closely in the following section.

In choosing a prestigious overseas publisher, Coetzee was not only reaching a much wider, international readership, but was also effectively insulating his authorship from the adverse political climate of the period, particularly the threat of arbitrary banning. With that choice, Coetzee also seems to have abandoned the Afrikaans-dialogue version of HOC, a decision that appears consistent with the general anti-Afrikaans mood which prevailed in the country after the Soweto uprising against enforced bilingual education. The eventual publication of the Afrikaans-English version of HOC, together with a resumption of a relationship with Ravan became possible, ironically, precisely because of the deteriorating political situation and the tightening of the censor's noose. ${ }^{8}$

In June 1977, Coetzee informed Randall that Secker \& Warburg "have at the last moment got cold feet about trying to market the book in South Africa. As matters stand, they don't even want to try". The British publisher was presumably anxious about importing a book that would in all likelihood be banned and embroil them in a messy political debacle. Coetzee also confided to Randall that he was trying to persuade Secker "to at least place the book before the censors" (14 June 1977). Coetzee's attempt to actively seek out the censor in order to secure approval appears odd, given his

$$
\text { https://repository.uwc.ac.za/ }
$$


subsequent public stance on the matter, but we must also consider that he was faced with the prospect of no South African distribution of HOC, thereby losing the book's most important reading community. In the preface to an anthology of South African writing, written in 1985, Coetzee and his co-editor Andre Brink recorded their defiance of the censorship laws:

[W]e must place on record that we agreed at the commencement of the project that we would proceed as if the apparatus of censorship did not exist. If the consequence of that decision was that our book would be prohibited in South Africa, we would live with that consequence. (1986: 15)

In 1977, faced with the prospect of HOC not being available in South Africa, Coetzee evidently found it difficult to "live with that consequence", going as far as working on a self-censored edition of the novel that would pass muster (see below). Spurred on by Coetzee's wish for a local distribution for HOC, Randall immediately agreed to publish a local edition of 1000 paperback copies, based on the Afrikaans dialogue version, on the understanding that Secker would not be bringing in any of their copies. He also telegraphed Coetzee in haste, warning him not to go ahead with his plan of placing the book before the censors. Randall's opposition to such a move was a matter of principle, but it would also have spelt ruin for the local Ravan publication: if HOC were banned there would no longer be any point in publishing, but also conversely, if the book was going to be found acceptable, Secker would no longer be deterred in bringing in their own stock. We can also speculate that Randall wanted to publish the book quietly, relying on substantial sales through the informal distribution networks that Ravan had set up.

Coetzee wrote back to Randall confirming his and Secker's agreement to the Ravan edition, but also added that Tom Rosenthal (Secker's editor) "has changed his plans slightly and, without putting the book before the censors, hopes to sell a couple of hundred copies here". This naturally increased the commercial and political risk for Ravan, but Coetzee suggested that Randall "consider producing an edition with a toned down blurb and four or five blanked out paragraphs" (5 July 1977). Randall was though worried that even a watered down edition would not be legally possible should HOC be banned. He wrote to Rosenthal pleading with him to hold off bringing their copies to South Africa: "if your copies are embargoed and submitted to the censors and if they find against the book, then we shall not be able to distribute our edition at all" (4 July 1977). He also promised Rosenthal to speed up his edition, even though he had not yet received the manuscript from Coetzee.

Rosenthal replied to Randall, sympathizing with his request, but explained that

$$
\text { https://repository.uwc.ac.za/ }
$$


since the author and we have had such immensely lengthy and convoluted discussions on this subject, we have already set in train the importation of a certain number of books and the despatch of a number of review copies from here which it is now too late to stop. We have done this after the most careful consideration and having the closest possible regard for the author's wishes. (12 July 1977)

He closed the letter, expressing his regret, hoping that "we both come out of this alive". Randall's instincts were right in this case, for the censors' records show that Secker \& Warburg's consignment of HOC was indeed embargoed by customs in Cape Town harbor on 11 July 1977, and referred to the censorship board for a decision. 9

In the July edition of the UCT News, Coetzee publically expressed his pessimism about the prospects of the novel: "It is unlikely that the book will be available in South Africa" (1977: 8). In a later press interview that month he sought to distance himself from this position saying that his remarks had been "private speculation being interpreted as gospel" and that it "would be most unwise for me to anticipate my decision by the Publications Control Board". ${ }^{10}$ Coetzee's prudence was however not shared by his British publisher. Coetzee had to inform Randall that Secker had sent out a "publicity notice about the book to the major South African newspapers ... It is obviously going to be impossible to keep the book as quiet as one would like" (8 July 1977). The South African press duly obliged by running a number of sensational reports. Under the lurid title "New SA novel explores black-white sex", an anonymous reporter in the Weekend World for instance wrote that Dr J.M. Coetzee's "sex across-the-colour-line" novel contributed to "calls for the scrapping of the Immorality Act and Mixed Marriages Act" (1977: 7). In highlighting the politically incendiary aspects of the book in their press release to the South African media (and not even supplying copies that would allow reviewers to make up their own minds), it is difficult to avoid the conclusion that Secker \& Warburg were deliberately attempting to foment public controversy. Secker's South African representative, Alison Samuel, in a sense threw down the gauntlet to the state when she publically announced that the book "does have content that may be objectionable to the South African Publications Control Board. But it is an extremely well-written experimental novel that deserves notice" (1977:7). Far from quietly slipping in a few copies, Secker \& Warburg was in effect broadcasting the fact that it was bringing a politically controversial novel on to the South African market, manufacturing a controversy that the censors would now certainly be unable to ignore. It is difficult to judge the motives here of Secker \& Warburg, but possibly a high-profile confrontation with the state along the lines of the Magersfontein debacle would enable them to occupy the moral high ground - and generate publicity for international sales.

In view of the publicity, Randall found himself in an increasingly tight corner, and asked Coetzee to prepare for the worst. This meant identifying offensive passages that could

$$
\text { https://repository.uwc.ac.za/ }
$$


possibly be omitted, and submitting a cut version to the censors (13 July 1977). Coetzee suggested three major deletions (Sections 206, 209 and 221) but asked Randall to go ahead with the original text, leaving the possibility open at the last minute to make changes. Coetzee's instructions in this matter were very precise, insisting on a text presentation that would not efface the censoring process, but make the cuts visible by replacing the omitted paragraphs with blanked out sections of similar length:

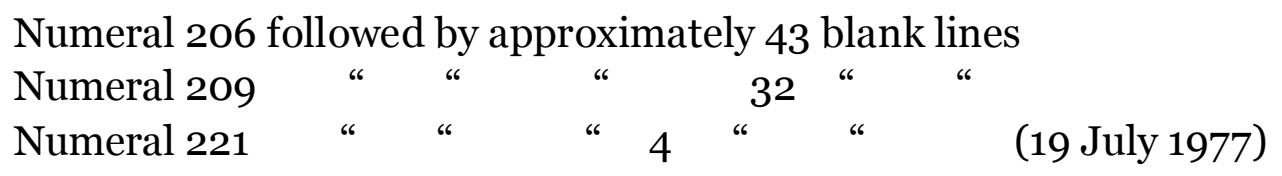

The selected sections all contained graphic descriptions of the rape and sexual humiliation of Magda, material that could be deemed "indecent or obscene or offensive or harmful to public morals" in terms of the censorship laws. ${ }^{11}$ Section 221 is cited in full to give a sense of the language that Coetzee thought might prove offensive:

He turns me on my face and does it to me from behind like an animal. Everything dies in me when I have to raise my ugly rear to him. I am humiliated; sometimes I think it is my humiliation he wants. (1977: 112)

But the multi-perspectival nature of Coetzee's narrative ensured that the events of the novel would still be knowable by the reader, even after substantial deletions. In HOC's non-linear narrative, simple cuts could not suppress the reader's ability to piece together a coherent account of the events. The same traumatic event, in this case the earlier rape of Magda, is narrated in different sections, each using a slightly different point of view. A comparison of sentences from section 206 (to be omitted) and section 207 (to be retained) makes this clear:

I pick up the first thing I see, a fork, and lunge with it, scraping his shoulder. The skin is not even pierced, but he sucks in his breath with surprise and hurls me against the wall, his whole weight upon me. The fork falls. His pelvis grinds hard into me. "No!"I say. "Yes!" he grunts an inch from my ear. (1977: 105)

He throws me against the wall, pinning my wrists, his whole weight upon me. The fork falls to the floor, his pelvis grinds hard into me. "No!"I say. "Yes!" he says. (1977:106)

The first quotation, from the section that Coetzee was proposing to delete, is part of a much longer paragraph in which the sexual violation is represented in more detail. But the reader would still be under no illusion what happened to Magda, since both section 205 and 206 represent the same incident.

\section{https://repository.uwc.ac.za/}


Although faced with the unpalatable prospect of mutilating his own novel, Coetzee finally also had some good news: according to inside information provided by fellow writer Elsa Joubert, HOC would in all likelihood not be banned. Joubert's source was impeccable: her husband sat on one of the censorship committees. The censors, he confided after reading the manuscript, were not any longer concerned about indecency but "attacks on police torture etc. ... are the current no-no" (19 July 1977). Interestingly, Coetzee's next novel, Waiting for the Barbarians (1980) would tackle precisely this theme, though its allegorical framing shielded it from censorship. ${ }^{12}$

The process of bringing the Afrikaans dialogue version of HOC to publication had embroiled Coetzee and Randall in a series of Kafkaesque entanglements with the censor, a situation Randall had hoped to avoid. In an atmosphere of political repression and uncertainty, accompanied by rumours, insider information and calculated risk-taking, Coetzee had been brought to the point of pre-emptive self-censorship. On hearing that the book had indeed been seized by the censors, an exasperated Randall exclaimed: "I sometimes think only lunatics try to publish anything other than travel guides and gardening books in this country!" (20 July 1977).

In hindsight, Coetzee's fears were misplaced and the censorship committee that considered HOC found it "not undesirable". The story of how HOC escaped the censors has already been told in detail by Peter McDonald in the Times Literary Supplement, and therefore only a brief summary is given here. What is striking is the contrast between Coetzee's imagined bureaucratic censors ("Censorship is not an occupation that attracts intelligent, subtle minds" (1996: viii)) and the actual situation. Unbeknown to Coetzee, the censorship committee that considered HOC comprised university academics (F.C. Fensham, a retired professor of Semitic Languages, and H. van der Merwe Scholtz, a professor of Afrikaans, and colleague at UCT), as well as the wellknown Afrikaans writer Anna M. Louw which whom Coetzee was even socially acquainted. All three readers of HOC praised its exceptional literary qualities and recommended unanimously that it be passed, notwithstanding some disturbing passages. Louw's report is especially noteworthy for its detailed and sympathetic engagement with the novel. She subsequently reworked the piece as a book review in the Afrikaans daily, Die Burger, calling HOC the "book of the year". Coetzee had evidently read the piece, for he suggested this quotation from it to Ravan as a possible blurb on the jacket cover of their edition. ${ }^{13}$ Inadvertently thus the voice of the censor insinuated itself into the very book that it was subjecting to scrutiny, thereby forming a bizarre and insidious circuit of simultaneous repression and endorsement.

When the censors eventually released HOC, Coetzee would have been relieved and he reported to Randall that Secker's representatives are "working briskly" and anticipated selling "a good few hundred copies on the South African market" (18 October 1977). This

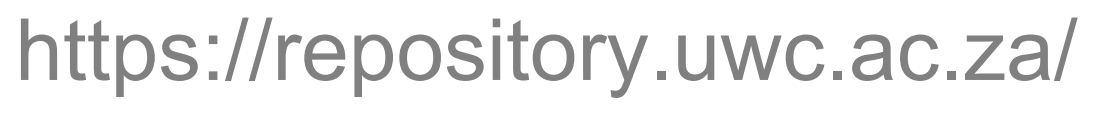


might have pleased Coetzee as an author, but for Randall the situation was still precarious from a publishing point of view. Ravan's bilingual edition was only due to appear early in 1978, and in the mean time Secker \& Warburg could sell their stock on the South African market, thereby compromising any sales Ravan could hope to achieve. In an unenviable position for a publisher, Randall had committed himself to a publication that had little prospects of commercial return.

Matters were to become worse when Randall was served by a five year banning order in November that forced him to relinquish his editorship of Ravan. Under the standard terms for banned persons, Randall had to report to a police station every week, and was prohibited from attending any meeting with more than two people. As banned persons could not be quoted or published, Randall was effectively muzzled. In the transition to Randall's successor, Mike Kirkwood, matters went also went awry with HOC. When Coetzee received the proofs of the novel, he was incensed to find that the section numbers had been removed:

The omission of the section numbers is a serious mistake and must be corrected. I don't know who took it upon himself to order their omission, but I was not consulted and would certainly not have authorized it ... The numbers have to be restored - there can be no argument about this. (1 December 1977)

Coetzee's tone and uncompromising stance may seem disproportionate in the case of a minor matter such as missing section numbers, especially as further changes involving lay-out and re-setting would delay publication even longer. But the section numbers were clearly important to Coetzee, indeed crucial to the entire conceptualization of HOC. As he explained to Joanna Scott, the enabling device in In the Heart of the Country turned out to be the numbering of the sections, because that enabled me to drop all pretense of continuity. After a few hundred words of prose, there comes a break - a three-digit number... They enable a certain sharpness of transition, or lack of smooth transition. (1997: 89-90)

Under Kirkwood's editorship, the section numbers were restored according to Coetzee's wishes, and the text was subjected to another round of rigorous proofreading. Coetzee also approved of the jacket design and blurb, and the book eventually appeared in February 1978. In view of the substantial Secker \& Warburg sales in South Africa, the Ravan print run was even further reduced to 700, hardly worth all the trouble and anxiety of the preceding months. ${ }^{14}$

In view of the fraught experience of publishing a local version of HOC in South Africa, it is perhaps more surprising that Coetzee continued his relationship with Ravan than that he did not. He had after all found a major international publisher in Secker \& Warburg

$$
\text { https://repository.uwc.ac.za/ }
$$


who was also able and willing to distribute his books in South Africa. The fact that Coetzee continued to co-publish with Ravan despite the unfavourable experience around HOC, seems likely to be attributable to three interrelated reasons. Firstly, the censorship regime began to shift markedly after 1978, culminating in the unbanning of Magersfontein in 1980 under the more enlightened chairmanship of Van Rooyen. Writing and publishing novels in South Africa would never be as difficult again after HOC. As Coetzee put it to the journalist Hugh Roberton, "nowadays the censors seem to take a much more tolerant and civilized attitude towards the question what will really corrupt the public morals" (1983: 12). Secondly, Coetzee would have found it attractive to work with Ravan's formidable new editor Mike Kirkwood, an English lecturer like himself and a major revisionist force in the South African literary studies. Kirkwood's and Coetzee's ideas about literature coincided in many respects, particularly their rejection of Leavisite criticism, the dominant paradigm in the South African academy at the time. Both shared a commitment to new, theoretically inflected modes of reading, and a revitalization of local literature. Apart from the novels, Kirkwood and Coetzee also collaborated on a number of other projects, including Kirkwood's new literary magazine Staffrider to which Coetzee contributed. Lastly, it is also clear that Coetzee continued to be interested in his home country and making a contribution to South African literature, particularly in the context of the radical publishing programme Kirkwood was embarking on with Ravan. In an earlier book review published in Beeld, Coetzee wrote about "the renewal that English prose is currently experiencing, a renewal led by our younger writers and smaller publishers" (my translation, 1975), making it clear that he saw himself part of this literary renaissance. As Andrew van der Vlies has argued in his examination of HOC,

Coetzee's apparent insistence on publishing a local, very South African version of his second novel, the first of his novels to be published abroad, and to do so despite (and after) British and American publication ... supports the ongoing re-evaluation of the extent to which his commitment to a radical politics in the country in the wake of the Soweto riots of 1976 is legible in the early novels - specifically in the circumstances of their publication. (2007: 135)

As shown in this paper, Coetzee's "commitment" to a nationally situated authorship evolved in a more complex and contradictory manner, shaped by both the particular historic conditions of the censorship regime at that time, as well as his recognition of the limitations of local publishing. The Secker \& Warburg edition arose out of Coetzee's wish to "break out of the local market" - and to sacrifice local publication, if necessary. The Ravan edition, on the other hand, emerged paradoxically out of a tightening censorship system in the post-Soweto period when Secker \& Warburg initially shied away from the South African market. Although the three subsequent novels, Waiting for the Barbarians (1980), Life \& Times of Michael K (1983) and Foe (1986) appeared

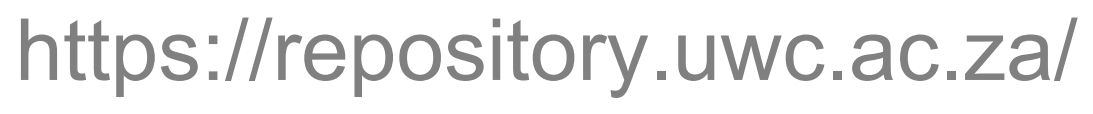


with Ravan as well, Coetzee would not again write a bilingual version of a novel for the local market, as would have been feasible with Life \& Times of Michael for example.

With the bilingual text of HOC, Coetzee had also come to the end of a form of authorship that was perhaps more Afrikaans than South African English in inflection. Coetzee's affinities to Afrikaans literary culture are worthwhile looking at in more detail, and HOC allows us to trace this engagement. When Dusklands appeared, Andre Brink as well as several other critics had lamented that fact that the novel had been written in English, and that Afrikaans literature had "lost a rich talent" (1974: 9). Brink (who himself wrote novels in both English and Afrikaans) saw Coetzee's literary affinities to the "Sestigers", the group of innovative Afrikaans writers of the previous decade. With HOC's original bilingual conception, Coetzee was possibly responding to this critique and exploring a form of authorship that differentiated itself sharply from the liberal South African English novelistic tradition (exemplified by Paton, Butler and Gordimer) - and foregrounded his affinities with an avant-garde Afrikaans literary culture. Extracts of HOC had after all first appeared in Standpunte, a prestigious and largely Afrikaans literary magazine under the editorship of Andre Brink. As several critics have pointed out, HOC was a rewriting of the 'plaasroman', a genre that Coetzee saw exemplified in the farm novels of the Afrikaans writer C.M van den Heever. Apart from HOC, Coetzee's engagement with Afrikaans literature is thus extensive, ranging from the literary criticism in White Writing and book reviews in Afrikaans newspapers to major translations from both Afrikaans and Dutch (Journey to the Baobab Tree, Achterberg et al).

With HOC, Coetzee was thus still experimenting with a bifurcated mode of authorship of which one strand was nationally situated, but with time he ultimately disengaged from the entanglements of the local. The next novel, Waiting for the Barbarians, would have a decidedly non-South African setting, marking a yet another visible break with the local English literary tradition exemplified by the liberal novel's coherence of character and landscape. It is clear then that the experiment of the vernacular edition of HOC was not going to be repeated, with the next novels edited and set by Secker \& Warburg in London. Ravan's role was reduced to that of a distributor and re-seller under license, although the books were re-jacketed for South African distribution, giving them a distinct local feel. The arrangement eventually ceased with Foe when a number of contractual differences finally ended dual publication. The fraught publishing history of HOC did thus not only shape Coetzee's authorship in significant ways, but also redefined his relationship to national culture, in particular his engagement with Afrikaans and his response to the censorship regime. Overall, Coetzee can be understood to have responded to the multiple pressures around HOC by not by disavowing the South African condition, but by becoming a transnational writer who could make meaning globally while still interpreting the local.

\section{https://repository.uwc.ac.za/}




\section{Works Cited}

Brink, A. 1974. “Is dié ‘Engelse Sestiger’'n aanklag teen onsself?” Rapport 19 May: 9.

Brink, A. and J. M. Coetzee, eds. 1986. Introduction. A Land Apart: A South African Reader. London: Faber \& Faber. 7-15.

Coetzee, J. M. 1975. "Lughartig, met erns.” Rev. of Local Colour, by Stephen Gray. Beeld 24 Nov.: 12.

- - . 1976. "In the Heart of the Country." Standpunte 12.4: 33-41.

-—-. 1977. In the Heart of the Country. London: Secker \& Warburg.

---. 1978. In the Heart of the Country. Johannesburg: Ravan.

-—-. 1988. "The Novel Today.” Upstream 6.1: 2-5.

-- . 1988. White Writing: On the Culture of Letters in South Africa. Johannesburg: Radix/Yale UP.

---. 1996. Giving Offense: Essays on Censorship. Chicago: Chicago UP.

Huggan, G. and S. Watson, eds. 1996. "Introduction." Critical Perspectives on J. M. Coetzee. London: Macmillan. 1-10.

Louw, A. 1977. "n Onvergeetlike Indruk." Rev. of In the Heart of the Country, by J. M. Coetzee. Die Burger 2 Dec.: 2.

Macmillan Press. J. M. Coetzee Files. Johannesburg.

McDonald, P. 2000. “'Not Undesirable': How J. M. Coetzee Escaped the Censor.” Times Literary Supplement 19 May: 14-15.

---. 2004. "The Writer, the Critic, and the Censor: J. M. Coetzee and the Question of Literature." Book History 7: 285-301.

National Archives of South Africa. Publications Control Archive: File on In the Heart of the Country, P77/7/103. Cape Town.

National English Literary Museum. Ravan Press Collection, 98.8.1.1-127. Grahamstown.

"New SA Novel Explores Black-White Sex.” Weekend World 31 July 1975: 7. 
Randall, P. 1997. "The Beginnings of Ravan Press: A Memoir." Ravan Twenty-Five Years (1972-1997): A Commemorative Volume of New Writin. Ed. G. E. de Villiers. Johannesburg: Ravan. 1-12.

---. 2007. Personal interview. 5 June.

- - . 2007. Unpublished notes on Ravan Press.

Roberton, H. 1983. "Positive Views on Publishing." The Argus 12 Aug.: 12. Scott, J. 1997. "Voice and Trajectory: An Interview with J. M. Coetzee." Salmagundi 114/115: 82-102. University of of Cape Town. 1977. UCT News 4.15: 8

Van der Vlies, A. 2004. "Introduction: The Institutions of South African Literature." English Studies in Africa 47.1: 1-15

---. 2007. South African Textual Cultures: White, Black, Read All Over. Manchester: Manchester UP.

Watson, S. 1978. “Speaking: J. M. Coetzee.” Speak 1.3: 21-24.

Zimbler, J. 2004. “Under Local Eyes: The SA Publishing Context of J. M. Coetzee's Foe.” English Studies in Africa 47.1: 45-59.

\section{Notes}

1 "Towards an Archaeology of Dusklands", forthcoming in J.M. Coetzee and the Aesthetics of Place, ed. Carol Clarkson, UCT Press.

${ }^{2}$ Coetzee reflected on these dual pressures most clearly in a talk, titled "The Novel Today", given at the Weekly Mail book fair in 1987. For him the writer was a "member of a tribe threatened with colonization". Coetzee argued for the independence of the novel in the highly charged political climate of South Africa under the state of emergency where there was "a tendency, a powerful tendency, perhaps even a dominant tendency, to subsume the novel under history” (1988:3).

3 The following archival sources were consulted: National English Literary Museum (NELM), Grahamstown: Ravan Press Collection, 98.8.1.1 - 127. The correspondence number marks are however not entirely chronological and therefore date references have been preferred in this paper. Coetzee's correspondence is also kept at the Macmillan Press Archive, Johannesburg, as well as the Spro-Cas Collection in the Cullen Library at the University of Witwatersrand. Permission to cite from the correspondence was kindly granted by J.M. Coetzee, Peter Randall, and Tom Rosenthal.

${ }^{4}$ Some of the work of Peter MacDonald on censorship, Andrew van der Vlies's recent book South African textual cultures (2007) and Jarad Zimbler's article on the Ravan edition of Foe are among the few examples.

${ }^{5}$ Ravan Press was one of South Africa's most prominent oppositional publishing houses, one of the few avant-garde presses that consistently defied the apartheid state, risking censorship and financial ruin by publishing black and radical writers. Founded as the publishing wing of the Christian Institute's SPRO-CAS project in 1972, it became an independent publisher by 1974, under the leadership of Peter Randall, Danie van Zyl and Beyers Naude (their surnames also provided the name "Ravan"). One of its flagship projects was the well-known literary magazine

\section{https://repository.uwc.ac.za/}


Staffrider, founded under the editorship of Mike Kirkwood. Randall later characterized Ravan's image as that of "a radical, risk-taking publisher prepared to test the limits of the apartheid state's tolerance" (1997:11).

${ }^{6}$ For a discussion of these shifts in the PCB, particularly Van Rooyen's new approach that centred on a "likely reader" rather than a more generic "man in the street", see Coetzee's chapter "Censorship in South Africa", in Giving Offence (1996).

${ }^{7}$ Coetzee was not strictly eligible on account of his age, but this condition was waived by Randall. Ravan administered the Mofolo-Plomer Prize which was established in 1976 through a joint donation by Nadine Gordimer and three Johannesburg publishers (Ravan, Bateleur Press and Ad. Donker). The prize, valued at R500.00, was awarded annually for the best unpublished literary manuscript, but was soon discontinued. Coetzee won the 1977 prize. ( 21 May 1976).

${ }^{8}$ Andrew van der Vlies has compared the two versions of HOC and has commented on the dual publication process, but his account does not explore the correspondence and is therefore more general in nature. See his chapter in South African textual cultures (2007).

${ }^{9}$ See the Publication Control Board file on In the Heart of the Country, P77/7/103, National Archives of South Africa, Cape Town.

${ }^{10}$ Coetzee's remarks are reported in the article "New SA novel explores black-white sex", Weekend World 31 July 1977.

${ }^{11}$ The Publication Control Act (1975) of the Republic of South Africa, cited in Coetzee's Giving Offence (1997: $185)$.

${ }^{12}$ See the Publication Control Board file on Waiting for the Barbarian, P80/11/205, National Archives of South Africa, Cape Town.

${ }^{13}$ Letter from J.M. Coetzee to Mike Kirkwood, dated 25 January 1978. Macmillan Press Archive, Johannesburg. Coetzee only recently became aware of the identity of his censors.

${ }^{14}$ Macmillan Press Archive, letter by Mike Kirkwood, 7 February 1978. 